\title{
Jordanian Voter's Criteria of Selection of Members of the Lower House of Representatives in 2013 Elections
}

\author{
Dr. Alaa Zuhair Rwashdeh \\ Associate Professor - Sociology, Department Of Social Sciences, Al-Balqa University, \\ Amman, Jordan \\ E-mail: alaa_rwashdeh@yahoo.com
}

Accepted: March 11, 2013 Published: April 26, 2013

Doi:10.5296/jsr.v4i1.3251ＵRL: http://dx.doi.org/10.5296/jsr.v4i1.3251

\begin{abstract}
This research aims at identifying the attributes that were viewed by the Jordanian voters as suitable and qualifying for a member of the Lower House of Representatives in the elections of 2013. These attributes were put in the following order, the candidate's ability to satisfy peoples' demands of public services, the candidate's academic qualifications, the candidate is not accused of corruption, the candidate's ability to keep the executive authority accountable, the candidate is religious, the candidate's kinship, the candidate's male gender, the candidate's family relationship, the candidate's ability to draw legislations, the candidate's economic situation, the candidate's female gender, the candidate's place of residence, whether the candidate would pay money for the vote, whether the candidate is a former MP and whether the candidate is a former Minister.
\end{abstract}

The order of above attributes varied according to the voters' categories, however, they have all agreed on the first two attributes which are: The candidate's ability to satisfy peoples' demands of public services and his academic qualification; the candidate being a former Minister came last.

Keywords: Criteria, elections, House of Representatives, candidate, society.

\section{Introduction}

Elections are viewed as a democratic means and a sound mechanism to bring about change in communities, provided that this process is free and honest, in addition to being a regular process, making room for new powers to join the process of voting and selecting their representatives and leaders and evaluate their performance as well as keep them accountable through the ballot box in periodical elections leading to the consolidation of the principles of peaceful transfer of power, in addition to the introduction of the principle of political, 
intellectual and partisan pluralism in the political system.

There is no doubt that elections are a constitutional and a political right and entitlement; as well, it is an advanced culture and energy of action moving all elements of the society. The overall situation - political, social, economic and external - at home is reflected on elections. Elections do devote a culture of dialogue, respect for the rule of law. Also, elections turn some concepts such as corruption, nepotism, bribery and non-institutionalism from being a feature and a sign of excellence to a blameworthy character which is renounced and resisted by the society.

One of the main requirements of the elections is a sense of internal freedom and a prevailing moderate logic which views policy as a tool to serve the homeland and the citizens and the political position as an assignment which goes so far to touch the least needs and humanitarian requirements in order to improve and upgrade them.

The Jordanian people have gone through many and diverse electoral experiences in a volatile circumstances. Through the years, circumstances have changed whether in regard to the voters' priorities or the nature, components and political orientation of the powers running for elections - pan national, Islamic, national or right, middle and left.

Elections are an opportunity to create a national Jordanian consensus regarding the means and mechanisms to set up national institutions on new basis away from corruption, chaos and favoritism to be based on accountability and transparency, leading to the setting up of a democratic state and allowing the Jordanian voters the opportunity to choose their representatives in the next Lower House of Representatives.

Nonetheless, the size of the actual impact of the upcoming parliamentary elections on the path of reform and modernization, accountability and transparency, which the Jordanian regime seeks to adopt and introduce, remains dependent to a large degree on the single personal and political characteristics of the elected persons, in addition to the total features of the Jordanian political map evolving after the elections, and the constituent powers thereof (supportive or opposing) as well as its' programs and directions and its' ability to create a commonly agreed new mechanisms of action to face the challenges and advance in the process of reform, modernization and development.

The parliamentary elections in 2013, unlike previous elections, specifically in 2007-2010, took place in inconvenient internal and external circumstances, these elections came as a result of lack of satisfaction on the part of the Jordanian citizens by the performance of members of the former Lower House of Representatives, 2007, and the sense of frustration of the role played by most members of the Lower House of Representatives in 2007, advancing the personal interests over the public interests, and the subsequent corruption cases... etc.

For these reasons and other factors, we believe that the Jordanian citizen has formulated a concept of descriptions seen as qualifying for the candidate he well select in the 


\section{Macrothink}

parliamentary elections for 2010, and this is what this study will try to investigate and analyze.

\section{The study statement of problem}

Every voter has a perception about the specifics of the candidate he intends to elect, and usually focuses on social, political, partisan, economic or social-gender related dimensions of the candidate, or all of these things together. This study focuses on the specifics and the parameters viewed by the voters as appropriate in the parliamentary elections in 2013 as well as the factors that influenced the selection of these attributes.

\section{Questions of the study}

This study attempts to answer the following questions:

- What attributes the Jordanian voter deems appropriate in the member of the Jordanian Lower House of Representatives in 2013?

- What social, economic and demographic factors influenced the selection of these attributes and the way they are set in order? i.e., are there statistically significant differences at the level of $(0.05 \geq \alpha)$ in the attributes seen by the Jordanian voter as appropriate for the member of the sixteenth Lower House of Representatives in 2013 due to the variables of gender, age, place of residence, educational level, and work?"

\section{Objectives of this study}

This study seeks to achieve the following objectives:

1. Clarification of the attributes seen by the Jordanian voter as appropriate in the member of the Jordanian Lower House of Representatives in 2013.

2. Categorization of these attributes according to their importance as seen by the Jordanian voter.

3. Identifying the social, economic and demographical factors which influenced the selection of these attributes and the way they are categorized? i.e., to identify the statistically significant differences at level $(0.05 \geq \alpha)$ of the attributes seen by the Jordanian voter as appropriate in the member of the Jordanian Lower House of Representatives in 2013 in the light of the variables gender, age, place of residence, educational level, and work.

\section{Importance and justification of the study}

The importance of the study stems from the fact that it is one of the rare studies which shed light on the subject of the attributes seen by the Jordanians voters as appropriate for the 
member of the next Lower House of Representatives. It provides the candidates and the decision-makers with the specifics and parameters which interest the voters when choosing a candidate, to help them make the right decision when determining the list of candidates to run for the next election. This issue constitutes an important field of search in humanities, social and psychological sciences, specifically in the field of general, political and organizational sociology, social psychology, and political science due to their role in determining the cognitive, emotional and behavioral structure of the voter, in one of the most important shapes and forms of democracy and political participation.

\section{Previous studies}

To the knowledge of the researcher, there are no previous specialized studies on the subject of the study on the situation of Jordan, However, some research centers in Jordan carried out public opinion polls in an attempt to identify the criteria followed by the Jordanian voters to choose candidates, but there are many studies and reports that addressed the issue of Jordanian elections in general, including:

- The study of The University of Jordan Center for Strategic Studies: in June 2010, who conducted a poll on "The new election law and electoral participation" which aimed at producing a public opinion poll about the new law and electoral participation, satisfaction, the penalties for the sale and purchase of votes, and voting of illiterate in addition to exploring the opinion of the respondents on increasing the parliamentary seats recently approved by the government as well as the process of votes organizing and transfer and voters registration.

The study covered (1182) persons from various Jordanian sectors and the result of this study showed that a moderate percentage of (62\%) expressed their satisfaction with the new law. The absence of mass media in informing citizens of the new law has had the greatest impact on the extent of satisfaction with this law, those who heard or saw or read about this new law did not exceed one-third (33\%) and (56\%) of these were from the Middle Region, (31\%) from the Northern Region and (13\%) of the South. Less than two thirds of the voters $(62 \%)$, believed that the new law will introduce deputies representing the citizens. The results indicated that $(65 \%)$ of respondents believed that the upcoming parliamentary elections will be fair and transparent, this moderate percentage is attributed to the lack of sufficient confidence in the government's ability to stop vote buying. In light of these findings the study recommended the following:

\section{First:}

To inform the Jordanian public of guarantees and sanctions which secure the integrity of the elections specifically the transfer and buying of votes.

\section{Second:}

To apply and activate these legal provisions on the ground. The first practical devotion of 
these provisions in respect of appeals in the voters' lists after its publication may be of a direct effect in enhancing the credibility of the electoral process.

\section{- Study of Al Mashreq AlJadid for Studies - Friday 28 - September 2010}

Entitled "The upcoming parliamentary elections," conducted on a sample Jordanians to study the problems of Jordan from all economic, social and political aspects as well as the situation of the Parliament, namely: economic aspects, problems of housing, low wages, and high prices, as well as debating the phenomenon of favoritism and nepotism, and giving attention to democracy and freedom to be tried out and the refusal by the youth of this idea ((and the belief that freedom is restricted in Jordan)), in addition to discussing the problems of education and university admissions and health insurance for the age group of 35 or above and the lack of medicines in hospitals and the submission of a proposal to restore the military service and paying attention to women's rights.

Upon debating these matters, they tried to find solutions thereof and put the goals of this study as follows:

- Introduction of the parliamentary elections attempting to show the development that took place in Jordan during the past four years.

- Identify the supporters and the opponents of these matters.

- Attempt to apply the democratic electoral atmosphere and fair elections without fraud and manipulation.

- Paying attention to the category of youth and their problems and try to adopt freedom.

- Not to manipulate the elections and support of tribal elections to be more government controlled.

- Resist the docility of individuals for their desire to vote by following the clan or according to the financial resources and pay for the vote.

Among the conclusions of above study are the following:

- Elimination of favoritism and nepotism

- Restoration of security

- Weak present parliamentary performance due to last elections.

- Lack of confidence by the voters in the electoral process due to lack of elections integrity.

- The deputies being interested in the electoral program to obtain more votes.

- The youth expressing their acceptance and consent of the Kings' confirmation of the importance of their role in the elections.

- The poor chances of success of the party candidates against the tribal candidates because the last is more honest and controlled.

- Elimination of high prices, unemployment and poverty more aggressively, is the utmost expected by the people from the Lower House of Representatives. 
Study of (Bani Amer, A. 2010) on the orientations of the youth to participate in the upcoming parliamentary elections to explore their views in the elections and the problems they face to exercise this right. The study was conducted on a sample of young people to measure their interests and political orientations and to clarify their role in influencing the political decision in the field of elections. The conclusions of the study were as follows:

- $74.1 \%$ have participated in the last elections.

- $17.5 \%$ are registered in districts outside their neighborhoods.

- $31 \%$ are ignorant of registration mechanisms

- Declining of tribal based selection of candidates in 2010

- $23.7 \%$ are not convinced of the role of the Lower House of Representatives.

- $14.6 \%$ Increase in the percentage of selection on the basis of the personal biography.

- 67.7 are optimistic about the integrity of the upcoming parliamentary elections.

- $37.7 \%$ are youth who know some information about the elections law.

- $72.4 \%$ supportive of the observation of elections by the Jordanian civil society institutions.

\section{Study of the International Republican Institute (2009)}

Opinion poll on the "democratization, and political reform in Jordan" conducted August 8 to 11, 2009 on a sample of 1000 people, who are aged 18 and above. Most important findings were that $58 \%$ of Jordanians believed that Jordan is moving in the right direction, against $29 \%$ who believed that matters are going in the wrong direction, and showed also the lack of confidence by the Jordanians both in the government and the Lower House of Representatives. The performance of the current parliament and the government recorded low satisfaction rates.

\section{Study of (Al-Masri, M. 2007) of The University of Jordan Center for Strategic Studies}

Who conducted a public opinion poll on "Assessment of the performance of the fourteenth Lower House of Representatives (2003 -2007) and the determinants of voting behavior during the upcoming parliamentary elections".

This study aimed at: Addressing the overall assessment of the Jordanian public opinion of the performance of the fourteenth Lower House of Representatives. This section includes data on the extent of knowledge of the public of the tasks of the Lower House of Representatives and its duties in general, and the political trends in the fourteenth Lower House of Representatives and the names of the deputies in their areas as well as data about the public's assessment of the performance of the fourteenth Lower House of Representatives in achieving its basic constitutional tasks: monitoring, accountability and control of public spending, in addition to respondents' evaluation of the performance of the House in dealing with issues that Jordan and the Arab region were exposed to as defined by citizens. 
The poll measures the extent of follow-up by the citizens of the performance of the fourteenth House of the Representatives in addition to their assessment of the independence of the fourteenth House and the main determinants of voting of the deputies during the period of the previous house from the perspective of the respondents and the extent of communication between the deputies and the citizens as well as the assessment of the respondents to the issue of parliamentary quota applied for the first time in the fourteenth Lower House of Representatives.

The second section aims at identifying the of public opinion's trends about the parliamentary elections in 2010 as well as identifying the determinants of voting behavior of citizens during the parliamentary elections, through knowing the opinions of respondents who would take part in the elections and their motives, in addition to the factors which they will take into account when voting for a candidate and the extent of citizens' participation in electoral campaigns and their expectations for the integrity of the parliamentary elections in 2010 .

The results showed that the assessment of public opinion to the fourteenth Lower House of Representatives in general was negative. The last House did not succeed, from the viewpoint of the respondents, in performing any of its constitutionally assigned roles in regard to the control over the executive authority, accountability, legislation, audit and control of public spending, and advocating the issues of citizens and their views. The percentage of respondents who reported that the fourteenth House had succeeded in handling any of its constitutionally assigned roles was less than (0.50\%) i.e., that the Council was not successful in fulfilling any of these tasks.

The assessment of the performance of the fourteenth House in dealing with the issues considered by the citizen's as priorities must be addressed such as: unemployment, poverty, rising prices was not better than the performance in completing its' constitutional tasks. The overall assessment of the House in dealing with important issues that Jordan and the Arab region were exposed to during its life (2003-2007) was negative). This negative evaluation of the performance of the fourteenth House in terms of carrying out its main tasks and in dealing with priority issues of the citizens reflected on the level of satisfaction of the public opinion regarding the performance of the House in general and the performance of the MPs of their constituencies. The results showed that less than $(0.50 \%)$ of the respondents were satisfied (and to varying degrees) of the performance of the fourteenth Lower House of Representatives or the MPs of their constituencies in the same House.

\section{Study of (Alotain, S. 2006)}

The study was entitled "political pluralism in light of the parliamentary elections in Jordan 1989-2005". The study aimed to diagnose the reality of the electoral law of Jordan through the analysis of the positive and negative benefits of to the electoral law applicable in Jordan as well as clarification of the relationship between the election law and the political pluralism 
and the contribution of the electoral law to the achievement of political pluralism. As Jordan is one of the countries that moved toward democracy and continued to build and deepen the democratic concepts in order to keep its political and social structure, hence, it can not afford to live in isolation from the world due to its location in tense and unstable region. The Principality of East Jordan, since its inception has been affected by important and variable local, national and international conditions which had a deep impact on the formation and work of the political and constitutional institutions, including parliaments. Jordan had followed since its inception the parliamentary system which promotes the right of participate, opposition and political pluralism. The Jordanian constitutions were committed to this approach in conformity with the well of Jordanian leadership to consolidate the foundations of democracy.

In order to determine the impact of the laws of the parliamentary elections on political pluralism the researcher analyzed the figures issued by the official bodies related to the results of the elections since 1989 until the 2003 elections and the effect of these laws on the participation in these elections, whether in view of individuals or the parties. This study included many tables showing the extent of participation in these elections and consequently the extent of satisfaction with these laws and whether these laws reflect the Jordanian street and the political elite's expectations as well as the effect of these laws on women's participation. The study was launched under the hypothesis that the (current) Election Law of Jordan adopting the one vote base has an impact on the political participation, several sub-hypotheses have emerged from this hypothesis, namely: the more the election law ensures equality of votes the greater political pluralism has increased. This was obvious to us through analyzing the results of parliamentary elections since 1989 to 2003 and comparing the results of elections made under the law of one vote; this is shown in the study through the tables. There is also another sub-hypothesis $\mathrm{w}$ is: the more the election law turns to the one vote base, the less political participation of the parties. The researcher used the historical method for the purposes of the study and therefore, the evolution of parliamentary life in Jordan since 1923_1989 was reviewed. The researcher also used systems analysis approach to determine the political pluralism situation in relation to amendments of the election laws from time to time.

The study concluded that the laws of the parliamentary elections affect negatively or positively the achievement of political pluralism, as the more the law is turning towards the one sound for one voter base, the less political pluralism is achieved, because each person begins to advance his sub affiliations: kinship, then the region or the party; and where the election law is more turning towards multi-voting, more political pluralism is achieved as the individual is more able to support the candidate of the tribe or the party and this is what this study has demonstrated.

\section{Study of (Zeod, M. E. 2000), Clan and Parliamentary Elections in Jordan:}

Aiming at identifying the role played by the clan in the parliamentary elections, as well as determining the impact of internal competition among the clan on the effectiveness of the 
tribal style. It has also aimed at revealing the ability of the clan as a traditional feature to accommodate and cope with the modern social structures and whether the clan was able to be a tributary alternative and a partner for these institutions. In order to achieve these objectives, a random sample of candidates was selected who represented $21 \%$ of the population of the total study's sample counting (178) individuals.

The descriptive statistics analytical method was adopted, whereas most important results indicated that the decision of the majority was of the most important mechanisms used in the selection by the clan of its candidate. The results of the one way analysis of variance (ANOVA) and the Chi square test showed the presence of statistically significant differences between the candidates and the MPs in connection with the variable of income and that wining the elections was affected by this variable.

The results showed also that there are statistically significant differences between the candidates and the MPs in the rate that reflects the role of the clan in the elections, most important of which is the support the clan of the nomination, social status within the clan etc. The results of the simple linear regression analysis showed statistically significant relations between the mechanisms of the clan in the selection of candidates and wining the elections.

This study concluded to a number of recommendations regarding conducting studies of the law of one vote for one voter and its impact on the role of the clan in the elections, in addition to conducting a study on the impact of the clan in the elections from the voters perspective.

\section{Study of (Elhourani, H. and others, 1998)}

Presented through his book "Studies in the parliamentary elections of Jordan 1997 Concluding that cultural and media related challenges represented effective constraints affecting the political participation of the Jordanian women, as they address the surface issues and concerns of women, and the prevailing culture represents another constraint facing women political participation.

\section{Study of (Alomari, I. 1997)}

About "the impact of the social politicization on the parliamentary elections in Jordan"

Aiming at providing a clear picture of the importance of motivating the political behavior of the individual and the transformation thereof into a reality represented in exercising the right to vote in accordance to basis of political awareness of the importance of the role of the one vote in determining the general policy of the state in the future, in addition to the advancement of the tactics that enable candidates to present their election programs and put them into effect in an effective and positive way and bring the views of the electoral process closer, which contributes to the advancement of the electoral process particularly and enrichment of the democratic life in general. 
The study concluded to recommendations that support its hypothesis: that the consolidation of the concept of social politicization through its clarification as well as through studying its factors and impact on the political behavior of both the voters and the candidates, will lead to the activation of the electoral process and the improvement of its results through the following:

1. Establishment of centers to enlighten individuals, especially the young of the parliamentary elections and everything related to them.

2. Activation of the role of various media means.

3. Backing the political upbringing in the educational institutions and the school curricula.

4. The reorganization of the political parties to activate their role.

5. Giving greater attention to electoral programs and improving communication methods both formal and informal between the candidate and the voter.

6. Establishment of centers of public opinion poll to provide various information related to the parliamentary elections.

\section{Study of (Al-Rai Newspaper, 1989)}

The parliamentary elections in a page of dialogue, in the month of August and September 2010, where conversations and interviews were conducted with the various segments of society to talk about the elections and the attributes of the MP we want, and the challenges facing Jordan as well as the role of Lower House of Representatives in dealing with them, in addition to an analysis of the electoral law based on one vote for one voter.

\section{Methodology and procedures of the study:}

\section{Method of study}

The study followed the method of sample social survey, in addition to the descriptive and statistical approach to achieve its objectives.

\section{The study population and its sample}

The study population was composed of all voters who were eligible to vote in the governorates of the Kingdom, and who have reached the age of 18 and above. Also included all types of rural and urban communities, and was applied on a purposive sample of 1200 researched, 600 of them were males and 600 females, 100 researched from each province. 


\section{Instrument of the study}

A special questionnaire was designed which consisted of two parts:

The first included the demographic characteristics of the study sample and the second included the attributes that voters deemed suitable it in the appropriate candidate for the upcoming elections and by 15 attributes. The forms were distributed by a trained research team in the period from 15.08.2012 to 15.11.2012; some incomplete forms were excluded and replaced with another reaching the required number of 1200 researched.

\section{Validity and Reliability of the Study Instrument}

The questionnaire was shown to a number of specialists and they were asked to make appropriate amendments: delete, add, modify, or language formulate to ensure the stability of the instrument. The internal consistency was calculated on a reconnaissance sample of 40 individuals (subject) from outside the study sample and reached 0.85 in accordance with the Cronbach's Alpha equation, which was considered appropriate for the purposes of this study. Averages were classified according to the following criteria:

\begin{tabular}{|lll|}
\hline Less than 0.33 & $=$ & Agree to a low degree \\
\hline From 0.33 to 0.66 & $=$ & Agree to a medium degree \\
\hline More than 0.66 & $=$ & Agree \\
\hline
\end{tabular}

\section{Statistical Processing}

In order to answer the questions of the study, frequencies and percentages were used as well as the arithmetic mean and the standard deviations to answer the second question, as for the third question, T- tests and analysis of variance (ANOVA) were used and Post Hoc Comparisons, Scheffe method were used to indicate the pairwise differences.

\section{Presentation of the study results}

Question 1: What are the demographic characteristics of the study sample?

To answer this question frequencies and percentages have been extracted as in Table (1).

The volume of the researched sample was 1200 individuals, including 600 males and 600 females, $55.8 \%$ of them were urban, and $44.2 \%$ were rural. And by age, the age group over 33 received the highest frequency which reached (495) individuals with a percentage of (41.3\%), while the frequency of the age group of 18-25 reached (352) individuals with a percentage of $(29.3 \%)$. However, according to educational level: the higher category of the High School received the highest frequency which reached (601) individuals with a percentage of $(50.1 \%)$, while the frequency of the category secondary or less reached (599) 
individuals with a percentage $(49.9 \%)$. As to the professional statues, the category of those who work received the highest frequency which reached (847) individuals with a percentage of $(70.6 \%)$, while the frequency of those who don't work reached (353) individuals with a percentage of $(29.4 \%)$.

Table No. (1)

Frequencies and percentages of the study sample

\begin{tabular}{|l|l|l|}
\hline Gender & Frequency & Percentage \\
\hline Male & 600 & 50 \\
\hline Female & 600 & 50 \\
\hline Total & 1200 & 100 \\
\hline Age & Frequency & Percentage \\
\hline $18-25$ & 352 & 29.3 \\
\hline $26-33$ & 353 & 29.4 \\
\hline More than 33 & 495 & 41.3 \\
\hline Total & 1200 & 100 \\
\hline Place of Residence & Frequency & Percentage \\
\hline Rural & 670 & 55.8 \\
\hline Urban & 530 & 44.2 \\
\hline Total & 1200 & 100 \\
\hline Educational level & Frequency & Percentage \\
\hline High School and below & 599 & 49.9 \\
\hline High School and over & 601 & 50.1 \\
\hline Total & 1200 & 100 \\
\hline Categories & Frequency & Percentage \\
\hline Working & 847 & 70.6 \\
\hline Not Working & 353 & 29.4 \\
\hline Total & 1200 & 100 \\
\hline
\end{tabular}

The first question: "What attributes the Jordanian voter deems appropriate in the member of the sixteenth Lower House of Representatives of Jordan in 2013?"

To answer this question, the arithmetic means and the standard deviations of the attributes which the voter deems appropriate in the member of the sixteenth Jordanian Lower House of Representatives in 2013 were extracted, and the table below illustrates this.

Table No. (2) 


\section{Macrothink}

Journal of Sociological Research

ISSN 1948-5468

2013, Vol. 4, No. 1

Arithmetic means and standard deviations of the clauses of the attributes that the Jordanian voter deems appropriate in the member of the sixteenth Jordanian Lower House of Representatives in 2013 in descending order according to the arithmetic means:

\begin{tabular}{|c|c|c|c|c|c|}
\hline $\begin{array}{l}\text { Serial } \\
\text { Number }\end{array}$ & Number & Items & $\begin{array}{l}\text { arithmetic } \\
\text { mean }\end{array}$ & $\begin{array}{l}\text { standard } \\
\text { deviation }\end{array}$ & Grade \\
\hline 1 & 12 & $\begin{array}{l}\text { The candidate } \\
\text { satisfies peoples } \\
\text { demands of public } \\
\text { services }\end{array}$ & 0.82 & 0.41 & High \\
\hline 2 & 3 & Educational Level & 0.69 & 0.46 & High \\
\hline 3 & 1 & $\begin{array}{l}\text { Not accused of } \\
\text { corruption }\end{array}$ & 0.66 & 0.48 & Moderate \\
\hline 4 & 14 & $\begin{array}{l}\text { The candidate is } \\
\text { able to keep the } \\
\text { executive authority } \\
\text { accountable }\end{array}$ & 0.6 & 0.51 & Moderate \\
\hline 5 & 5 & $\begin{array}{l}\text { The candidate is } \\
\text { religious }\end{array}$ & 0.5 & 0.5 & Moderate \\
\hline 6 & 2 & Kinship & 0.49 & 0.5 & Moderate \\
\hline 7 & 7 & $\begin{array}{l}\text { The candidate is } \\
\text { male }\end{array}$ & 0.47 & 0.5 & Moderate \\
\hline 8 & 9 & Family relationship & 0.46 & 0.5 & Moderate \\
\hline 9 & 13 & $\begin{array}{l}\text { The candidate is } \\
\text { able to draw } \\
\text { legislations }\end{array}$ & 0.45 & 0.52 & Moderate \\
\hline 10 & 11 & $\begin{array}{l}\text { The economic } \\
\text { situation of the } \\
\text { candidate }\end{array}$ & 0.28 & 0.47 & Low \\
\hline 11 & 6 & $\begin{array}{l}\text { The candidate is } \\
\text { female }\end{array}$ & 0.25 & 0.43 & Low \\
\hline 12 & 4 & $\begin{array}{l}\text { Place of residence } \\
\text { of the candidate }\end{array}$ & 0.2 & 0.4 & Low \\
\hline 13 & 15 & $\begin{array}{l}\text { Whether the } \\
\text { candidate pays } \\
\text { money for votes }\end{array}$ & 0.18 & 0.39 & Low \\
\hline 14 & 8 & $\begin{array}{l}\text { Whether the } \\
\text { candidate is a } \\
\text { former MP }\end{array}$ & 0.17 & 0.37 & Low \\
\hline 15 & 10 & $\begin{array}{l}\text { Whether the } \\
\text { candidate is a }\end{array}$ & 0.09 & 0.28 & Low \\
\hline
\end{tabular}


Table (2) shows the arithmetic means and the standard deviations of the clauses of the attributes that the Jordanian voter deems appropriate in the member of the sixteenth Jordanian Lower House of Representatives in 2013 put in descending order according to the arithmetic means:

Whereby paragraph (12), which states that " The candidate satisfies peoples demand of public services" in the first place, with an arithmetic mean of (0.82) and a high grade, followed in the second place by paragraph (3), which reads "Educational level" with an arithmetic mean of (0.69) and a high degree, and then came paragraph (1), which reads "is not accused of corruption," with an arithmetic mean of (0.66) and a moderate degree, while came next and last paragraph (10) which reads " the candidate is a former Minister" with an arithmetic mean of (0.09) and a low degree. It is noted, however, that ten out of the fifteen attributes gained great and moderate attention of the Jordanian voter.

The second question: "Are there statistically significant differences at the level of $(\alpha \leq 0.05)$ in the attributes seen by the Jordanian voter as appropriate in the member of the sixteenth House of Representatives of Jordan in 2013 due to the variables of sex, age, place of residence, educational level, and work?"

To answer this question, arithmetic means and standard deviations have been extracted for the attributes seen by the Jordanian voter as appropriate in member of the sixteenth Jordanian Lower House of Representatives in 2013 due to the variables sex, age, place of residence, educational level, employment, and to indicate significant statistical differences between the arithmetic means (T) test was used for sex, place of residence, level of education, work and the single analysis of variance for age, and the tables below illustrate this: 


\section{Macrothink}

First: Sex

Table (3)

\begin{tabular}{|c|c|c|c|c|c|c|}
\hline & Male & & Female & & & \\
\hline & $\begin{array}{l}\text { Arithmetic } \\
\text { Mean }\end{array}$ & $\begin{array}{l}\text { Standard } \\
\text { Deviation }\end{array}$ & $\begin{array}{l}\text { Arithmetic } \\
\text { Mean }\end{array}$ & $\begin{array}{l}\text { Standard } \\
\text { Deviation }\end{array}$ & $\begin{array}{l}\text { T } \\
\text { Value }\end{array}$ & $\begin{array}{l}\text { Statistical } \\
\text { significance }\end{array}$ \\
\hline $\begin{array}{l}\text { Not } \\
\text { accused of } \\
\text { corruption }\end{array}$ & 0.67 & 0.47 & 0.65 & 0.48 & 0.789 & 0.43 \\
\hline Kinship & 0.56 & 0.5 & 0.41 & 0.49 & 5.373 & 0 \\
\hline $\begin{array}{l}\text { Educational } \\
\text { Level }\end{array}$ & 0.64 & 0.48 & 0.73 & 0.44 & -3.566 & 0 \\
\hline $\begin{array}{l}\text { Place of } \\
\text { residence } \\
\text { of the } \\
\text { candidate }\end{array}$ & 0.19 & 0.39 & 0.22 & 0.41 & -1.144 & 0.253 \\
\hline $\begin{array}{l}\text { The } \\
\text { candidate is } \\
\text { religious }\end{array}$ & 0.46 & 0.5 & 0.55 & 0.5 & -3.011 & 0.003 \\
\hline $\begin{array}{l}\text { The } \\
\text { candidate is } \\
\text { female }\end{array}$ & 0.14 & 0.35 & 0.35 & 0.48 & -8.42 & 0 \\
\hline $\begin{array}{l}\text { The } \\
\text { candidate is } \\
\text { male }\end{array}$ & 0.55 & 0.5 & 0.4 & 0.49 & 5.2 & 0 \\
\hline $\begin{array}{l}\text { The } \\
\text { candidate is } \\
\text { a former } \\
\text { MP }\end{array}$ & 0.16 & 0.36 & 0.18 & 0.39 & -1.234 & 0.217 \\
\hline $\begin{array}{l}\text { Family } \\
\text { relationship }\end{array}$ & 0.52 & 0.5 & 0.39 & 0.49 & 4.495 & 0 \\
\hline $\begin{array}{l}\text { The } \\
\text { candidate is } \\
\text { a former } \\
\text { Minister }\end{array}$ & 0.07 & 0.26 & 0.1 & 0.3 & -1.943 & 0.052 \\
\hline $\begin{array}{l}\text { The } \\
\text { Economic } \\
\text { Situation of } \\
\text { the } \\
\text { Candidate }\end{array}$ & 0.29 & 0.45 & 0.27 & 0.48 & 0.861 & 0.389 \\
\hline
\end{tabular}




\section{Macrothink}

\begin{tabular}{|l|l|l|l|l|l|l|}
\hline $\begin{array}{l}\text { The } \\
\text { candidate } \\
\text { satisfies } \\
\text { peoples } \\
\text { demands of } \\
\text { public } \\
\text { services }\end{array}$ & 0.81 & 0.4 & 0.84 & 0.42 & -1.273 & 0.203 \\
\hline $\begin{array}{l}\text { The } \\
\text { candidate is } \\
\text { able to } \\
\text { draw } \\
\text { legislations }\end{array}$ & 0.46 & 0.5 & 0.45 & 0.54 & 0.223 & 0.824 \\
\hline $\begin{array}{l}\text { The } \\
\text { candidate is } \\
\text { able to } \\
\text { keep the } \\
\text { executive } \\
\text { authority } \\
\text { accountable }\end{array}$ & 0.6 & & & & & \\
\hline $\begin{array}{l}\text { Whether } \\
\text { the } \\
\text { candidate } \\
\text { pays } \\
\text { money for } \\
\text { votes }\end{array}$ & 0.22 & 0.49 & 0.61 & 0.53 & -0.567 & 0.571 \\
\hline
\end{tabular}

Table (3) above shows the presence of statistically significant differences $(\alpha \leq 0.05)$ due to the effect of sex in clauses of kinship, qualifications, the fact that the candidate is religious, the fact that the candidate is female, the fact that the candidate is male, family affiliation, and the fact that the candidate pays money for the vote.

Differences came in favor of males in each of: kinship, the fact that the candidate is male, family affiliation, and the fact that the candidate pays money for the vote; this perhaps is due to the fact that males are more involved with the community and therefore they need male deputies of the relatives, and from known families, who are able to spend money to help them when exposed to financial distress. while the differences came in favor of females in each of the qualifications, the fact that the candidate is religious, and the fact that the candidate is female because females are less involved and interaction with the social reality and therefore, they concentrate on ideal standards more than males. No statistically significant differences were found in other attributes. 
Second: Age

Table (4)

Arithmetic means, standard deviations and the single analysis of variance according to the "age" variable of the clauses of the attributes which the Jordanian voter deems appropriate in the member of the sixteenth Jordanian Lower House of Representatives in 2013.

\begin{tabular}{|c|c|c|c|c|c|c|c|c|}
\hline & \multicolumn{2}{|c|}{ From 18 - 25} & \multicolumn{2}{|c|}{ From 26 - 33} & \multicolumn{2}{|c|}{ More than 33} & \multirow[b]{2}{*}{$\begin{array}{l}\mathbf{P} \\
\text { Value }\end{array}$} & \multirow[b]{2}{*}{$\begin{array}{l}\text { Statistical } \\
\text { Significance }\end{array}$} \\
\hline & $\begin{array}{l}\text { Arithmetic } \\
\text { Mean }\end{array}$ & $\begin{array}{l}\text { Deviation } \\
\text { Standard }\end{array}$ & $\begin{array}{l}\text { Arithmetic } \\
\text { Mean }\end{array}$ & $\begin{array}{l}\text { Deviation } \\
\text { Standard }\end{array}$ & $\begin{array}{l}\text { Arithmetic } \\
\text { Mean }\end{array}$ & $\begin{array}{l}\text { Deviation } \\
\text { Standard }\end{array}$ & & \\
\hline $\begin{array}{l}\text { not accused of } \\
\text { corruption }\end{array}$ & 0.61 & 0.49 & 0.67 & 0.47 & 0.68 & 0.47 & 2.603 & 0.074 \\
\hline Kinship & 0.44 & 0.5 & 0.45 & 0.5 & 0.54 & 0.5 & 5.489 & 0.004 \\
\hline Educational Level & 0.7 & 0.46 & 0.73 & 0.44 & 0.64 & 0.48 & 4.354 & 0.013 \\
\hline $\begin{array}{l}\text { Place of residence of } \\
\text { the candidate }\end{array}$ & 0.22 & 0.42 & 0.2 & 0.4 & 0.2 & 0.4 & 0.437 & 0.646 \\
\hline $\begin{array}{l}\text { The candidate is } \\
\text { religious }\end{array}$ & 0.53 & 0.5 & 0.51 & 0.5 & 0.49 & 0.5 & 0.557 & 0.573 \\
\hline $\begin{array}{l}\text { The candidate is } \\
\text { female }\end{array}$ & 0.27 & 0.44 & 0.25 & 0.43 & 0.22 & 0.42 & 1.183 & 0.307 \\
\hline The candidate is male & 0.44 & 0.5 & 0.45 & 0.5 & 0.51 & 0.5 & 2.856 & 0.058 \\
\hline $\begin{array}{l}\text { The candidate is a } \\
\text { former MP }\end{array}$ & 0.18 & 0.38 & 0.19 & 0.39 & 0.15 & 0.36 & 1.141 & 0.32 \\
\hline Family relationship & 0.44 & 0.5 & 0.48 & 0.5 & 0.46 & 0.5 & 0.525 & 0.592 \\
\hline $\begin{array}{l}\text { The candidate is a } \\
\text { former Minister }\end{array}$ & 0.1 & 0.3 & 0.1 & 0.31 & 0.07 & 0.25 & 1.944 & 0.144 \\
\hline $\begin{array}{ll}\text { The } & \text { economic } \\
\text { situation } & \text { of the } \\
\text { candidate } & \end{array}$ & 0.31 & 0.53 & 0.29 & 0.46 & 0.24 & 0.43 & 2.307 & 0.1 \\
\hline $\begin{array}{l}\text { The candidate satisfies } \\
\text { peoples demands of } \\
\text { public services }\end{array}$ & 0.86 & 0.43 & 0.83 & 0.38 & 0.79 & 0.41 & 3.856 & 0.021 \\
\hline $\begin{array}{l}\text { The candidate is able } \\
\text { to draw legislations }\end{array}$ & 0.44 & 0.56 & 0.42 & 0.49 & 0.49 & 0.5 & 1.848 & 0.158 \\
\hline $\begin{array}{l}\text { The candidate is able } \\
\text { to keep the executive } \\
\text { authority accountable }\end{array}$ & 0.67 & 0.54 & 0.59 & 0.49 & 0.57 & 0.5 & 4.378 & 0.013 \\
\hline $\begin{array}{l}\text { Whether the candidate } \\
\text { pays money for votes }\end{array}$ & 0.25 & 0.43 & 0.18 & 0.38 & 0.14 & 0.35 & 7.981 & 0 \\
\hline
\end{tabular}




\section{Macrothink}

Table (4) above shows the existence of statistically significant differences $(\alpha \leq 0.05)$ due to the impact of age in each of: kinship, educational level, the candidate satisfies peoples demands of public services, the candidate is able to keep the executive authority accountable, and Whether the candidate pays money for votes, and to indicate the statistically significant pairwise differences between arithmetic means Post Hoc Comparisons, Scheffe method were used as shown in table (5) below, while no statistically significant differences were found in the rest of the attributes.

\section{Table (5)}

Post Hoc Comparisons, Scheffe method of the impact of age on the attributes that the Jordanian voter deems appropriate in the member of the Jordanian sixteenth Lower House of Representatives of Jordan in 2013.

\begin{tabular}{|c|c|c|c|c|c|}
\hline & & $\begin{array}{l}\text { 'Arithmetic } \\
\text { Mean }\end{array}$ & $\begin{array}{l}\text { From } 18- \\
25\end{array}$ & $\begin{array}{l}\text { From } 26- \\
33\end{array}$ & $\begin{array}{l}\text { More than } \\
33\end{array}$ \\
\hline \multirow[t]{3}{*}{ Kinship } & $\begin{array}{l}\text { From } 18- \\
25\end{array}$ & 0.44 & & & \\
\hline & $\begin{array}{l}\text { From } 26- \\
33\end{array}$ & 0.45 & 0.01 & & \\
\hline & $\begin{array}{l}\text { More than } \\
33\end{array}$ & 0.54 & $.10^{*}$ & $.09 *$ & \\
\hline \multirow[t]{3}{*}{ Educational Level } & $\begin{array}{l}\text { From } 18- \\
25\end{array}$ & 0.7 & & & \\
\hline & $\begin{array}{l}\text { From } 26- \\
33\end{array}$ & 0.73 & 0.03 & & \\
\hline & $\begin{array}{l}\text { More than } \\
33\end{array}$ & 0.64 & 0.06 & $.09 *$ & \\
\hline \multirow{3}{*}{$\begin{array}{l}\text { The candidate satisfies } \\
\text { peoples demands of } \\
\text { public services }\end{array}$} & $\begin{array}{l}\text { From } 18- \\
25\end{array}$ & 0.86 & & & \\
\hline & $\begin{array}{l}\text { From } 26- \\
33\end{array}$ & 0.83 & 0.03 & & \\
\hline & $\begin{array}{l}\text { More than } \\
33\end{array}$ & 0.79 & $.08 *$ & 0.04 & \\
\hline \multirow{3}{*}{$\begin{array}{l}\text { The candidate is able to } \\
\text { keep the executive } \\
\text { authority accountable }\end{array}$} & $\begin{array}{l}\text { From } 18- \\
25\end{array}$ & 0.67 & & & \\
\hline & $\begin{array}{l}\text { From } 26- \\
33\end{array}$ & 0.59 & 0.08 & & \\
\hline & $\begin{array}{l}\text { More than } \\
33\end{array}$ & 0.57 & $.10^{*}$ & 0.02 & \\
\hline Whether the candidate & From $18-$ & 0.25 & & & \\
\hline
\end{tabular}




\begin{tabular}{|l|l|l|l|l|l|}
\hline pays money for votes & 25 & & & & \\
\cline { 2 - 6 } & $\begin{array}{l}\text { From 26 - } \\
33\end{array}$ & 0.18 & $.07^{*}$ & & \\
\hline & $\begin{array}{l}\text { More than } \\
33\end{array}$ & 0.14 & $.11^{*}$ & 0.03 & \\
\hline
\end{tabular}

$*$ Function when the level of significance $(\alpha \leq 0.05)$

Table (5) shows the following:

- The presence of statistically significant differences $(\alpha \leq 0.05)$ among the age group of more than 33 years on the one hand and all of the age groups between 18-25 and 2633 on the other hand; these differences were in favor of the age group over 33 years whose criteria of selection may have concentrated on kinship more than the other age groups.

- The presence of statistically significant differences $(\alpha \leq 0.05)$ among those aged more than 33 years, and 26-33; these difference were more in favor of the group over 26-33 years, in the educational level, this, perhaps, is due to this age group being more interested in education than the age group above 33 years old, and therefore, they were more appreciative of the educated.

- The presence of statistically significant differences $(\alpha \leq 0.05)$ among those aged more than 33 years, and 18-25; these difference were more in favor of the group over 18-25 years, in the "The candidate satisfies peoples demands of public services"; this, perhaps is due to the fact that this age group in particular the most in need of the MP who is able to satisfy its requirements, especially in finding jobs and scholarships.

- The presence of statistically significant differences $(\alpha \leq 0.05)$ among those aged more than 33 years, and 18-25; these difference were more in favor of the group over 18-25 years, in the "The candidate is able to keep the executive authority accountable".

- The presence of statistically significant differences $(\alpha \leq 0.05)$ among the age group $18-25$ on the one hand and each of the age groups 26-33 and more than 33 on the other hand; these differences were in favor of the age group 18-25 years in connection with "Whether the candidate pays money for votes"; this, perhaps is due to the hard economical conditions of unemployment and poverty this age group is undergoing.

\section{Third: Place of Residence}

Table (6)

Arithmetic means, standard deviations and " $T$ " test according to the "place of residence" 
variable of the attributes which the Jordanian voter deems appropriate in the member of the sixteenth Jordanian Lower House of Representatives in 2013.

\begin{tabular}{|c|c|c|c|c|c|c|}
\hline & \multicolumn{2}{|l|}{ Rural } & \multicolumn{2}{|l|}{ Urban } & \multirow[b]{2}{*}{$\begin{array}{l}\text { T } \\
\text { Value }\end{array}$} & \multirow[b]{2}{*}{$\begin{array}{l}\text { Statistical } \\
\text { significance }\end{array}$} \\
\hline & $\begin{array}{l}\text { Arithmetic } \\
\text { Mean }\end{array}$ & $\begin{array}{l}\text { Standard } \\
\text { Deviation }\end{array}$ & $\begin{array}{l}\text { Arithmetic } \\
\text { Mean }\end{array}$ & $\begin{array}{l}\text { Standard } \\
\text { Deviation }\end{array}$ & & \\
\hline Not accused of corruption & 0.71 & 0.45 & 0.58 & 0.49 & 4.637 & 0 \\
\hline Kinship & 0.5 & 0.5 & 0.47 & 0.5 & 0.922 & 0.357 \\
\hline Educational Level & 0.63 & 0.48 & 0.76 & 0.43 & -4.759 & 0 \\
\hline Place of residence of the candidate & 0.17 & 0.38 & 0.25 & 0.43 & -3.375 & 0.001 \\
\hline The candidate is religious & 0.43 & 0.5 & 0.6 & 0.49 & -6.056 & 0 \\
\hline The candidate is female & 0.2 & 0.4 & 0.3 & 0.46 & -4.1 & 0 \\
\hline The candidate is male & 0.41 & 0.49 & 0.55 & 0.5 & -5.005 & 0 \\
\hline The candidate is a former MP & 0.17 & 0.38 & 0.16 & 0.37 & 0.344 & 0.731 \\
\hline Family relationship & 0.46 & 0.5 & 0.45 & 0.5 & 0.405 & 0.685 \\
\hline The candidate is a former Minister & 0.05 & 0.22 & 0.13 & 0.34 & -4.905 & 0 \\
\hline $\begin{array}{l}\text { The Economic Situation of the } \\
\text { Candidate }\end{array}$ & 0.25 & 0.43 & 0.31 & 0.51 & -2.03 & 0.043 \\
\hline $\begin{array}{l}\text { The candidate satisfies peoples } \\
\text { demands of public services }\end{array}$ & 0.8 & 0.4 & 0.84 & 0.42 & -1.641 & 0.101 \\
\hline $\begin{array}{l}\text { The candidate is able to draw } \\
\text { legislations }\end{array}$ & 0.38 & 0.48 & 0.55 & 0.54 & -5.89 & 0 \\
\hline $\begin{array}{l}\text { The candidate is able to keep the } \\
\text { executive authority accountable }\end{array}$ & 0.55 & 0.5 & 0.68 & 0.51 & -4.53 & 0 \\
\hline $\begin{array}{l}\text { Whether the candidate pays money } \\
\text { for votes }\end{array}$ & 0.18 & 0.39 & 0.19 & 0.39 & -0.209 & 0.835 \\
\hline
\end{tabular}

Table (6) shows the presence of statistically significant differences $(\alpha \leq 0.05)$ due to the "place of residence" in all categories except the "kinship", the "The candidate is a former MP", the "Family relationship", the "The candidate satisfies peoples demands of public services" and the "Whether the candidate pays money for votes". Differences were in favor of the "Urban" in each of the categories: "Educational Level", "Place of residence of the candidate", "The candidate is religious", "The candidate is female", "The candidate is male", "The candidate is a former Minister", "The Economic Situation of the Candidate", "The candidate is able to draw legislations", "The candidate is able to keep the executive authority accountable"; while these differences were in favor of the "Rural" in the category "Not accused of corruption"; keeping in mind that the previous studies of the parliamentary elections in Jordan showed more interest of the rural population than the urban population, as in the study of (Elhorani and others 1997). 


\section{Fourth: Educational Level}

\section{Table (7)}

Arithmetic means, standard deviations and "T" test due to the variable "educational level" of the attributes which the Jordanian voter deems appropriate in the member of the sixteenth Jordanian Lower House of Representatives in 2013.

\begin{tabular}{|c|c|c|c|c|c|c|}
\hline & \multicolumn{2}{|c|}{ Below High School } & \multicolumn{2}{|c|}{ Above High School } & \multirow[b]{2}{*}{$\begin{array}{l}\mathbf{T} \\
\text { Value }\end{array}$} & \multirow[b]{2}{*}{$\begin{array}{l}\text { Statistical } \\
\text { significance }\end{array}$} \\
\hline & $\begin{array}{l}\text { Arithmetic } \\
\text { Mean }\end{array}$ & $\begin{array}{l}\text { Standard } \\
\text { Deviation }\end{array}$ & $\begin{array}{l}\text { Arithmetic } \\
\text { Mean }\end{array}$ & $\begin{array}{l}\text { Standard } \\
\text { Deviation }\end{array}$ & & \\
\hline Not accused of corruption & 0.61 & 0.49 & 0.7 & 0.46 & -3.151 & 0.002 \\
\hline Kinship & 0.61 & 0.49 & 0.36 & 0.48 & 8.748 & 0 \\
\hline Educational Level & 0.6 & 0.49 & 0.78 & 0.42 & -6.695 & 0 \\
\hline Place of residence of the candidate & 0.18 & 0.38 & 0.23 & 0.42 & -2.406 & 0.016 \\
\hline The candidate is religious & 0.5 & 0.5 & 0.51 & 0.5 & -0.172 & 0.863 \\
\hline The candidate is female & 0.22 & 0.41 & 0.27 & 0.45 & -2.252 & 0.024 \\
\hline The candidate is male & 0.49 & 0.5 & 0.45 & 0.5 & 1.385 & 0.166 \\
\hline The candidate is a former MP & 0.18 & 0.38 & 0.16 & 0.37 & 0.643 & 0.52 \\
\hline Family relationship & 0.53 & 0.5 & 0.38 & 0.49 & 5.146 & 0 \\
\hline The candidate is a former Minister & 0.08 & 0.26 & 0.1 & 0.3 & -1.515 & 0.13 \\
\hline $\begin{array}{l}\text { The Economic Situation of the } \\
\text { Candidate }\end{array}$ & 0.28 & 0.45 & 0.27 & 0.49 & 0.28 & 0.78 \\
\hline $\begin{array}{l}\text { The candidate satisfies peoples } \\
\text { demands of public services }\end{array}$ & 0.85 & 0.36 & 0.8 & 0.45 & 2.241 & 0.025 \\
\hline $\begin{array}{l}\text { The candidate is able to draw } \\
\text { legislations }\end{array}$ & 0.45 & 0.5 & 0.46 & 0.54 & -0.172 & 0.863 \\
\hline $\begin{array}{l}\text { The candidate is able to keep the } \\
\text { executive authority accountable }\end{array}$ & 0.53 & 0.5 & 0.68 & 0.51 & -5.321 & 0 \\
\hline $\begin{array}{l}\text { Whether the candidate pays money } \\
\text { for votes }\end{array}$ & 0.22 & 0.41 & 0.15 & 0.36 & 2.94 & 0.003 \\
\hline
\end{tabular}

Table (7) shows the presence of statistically significant differences $(\alpha \leq 0.05)$ due to the "Educational Level" in each of the "Not accused of corruption", the "Kinship", the "Educational Level", the "Place of residence of the candidate", the "The candidate is female", the "Family relationship", the "The candidate satisfies peoples demands of public services", the "The candidate is able to keep the executive authority accountable", the "Whether the candidate pays money for votes". Differences were in favor of the "Above High School" in each of the categories: "Not accused of corruption", "Educational Level", "Place of residence of the candidate", "The candidate is female", "The candidate is male", "The candidate is able to keep the executive authority accountable", and in favor of the "Below High School" in 
each of the categories: "Kinship", "Family relationship", "The candidate satisfies peoples demands of public services"; "Whether the candidate pays money for votes" while no statistically significant differences appeared in the rest of the attributes because the educated are more aware, knowledgeable and able to understand, analyze, and select of those who are less educated.

\section{Fifth: Work}

Table (8)

Arithmetic means, standard deviations and " $T$ " test due to the variable "Work" of the attributes which the Jordanian voter deems appropriate in the member of the sixteenth Jordanian Lower House of Representatives in 2013.

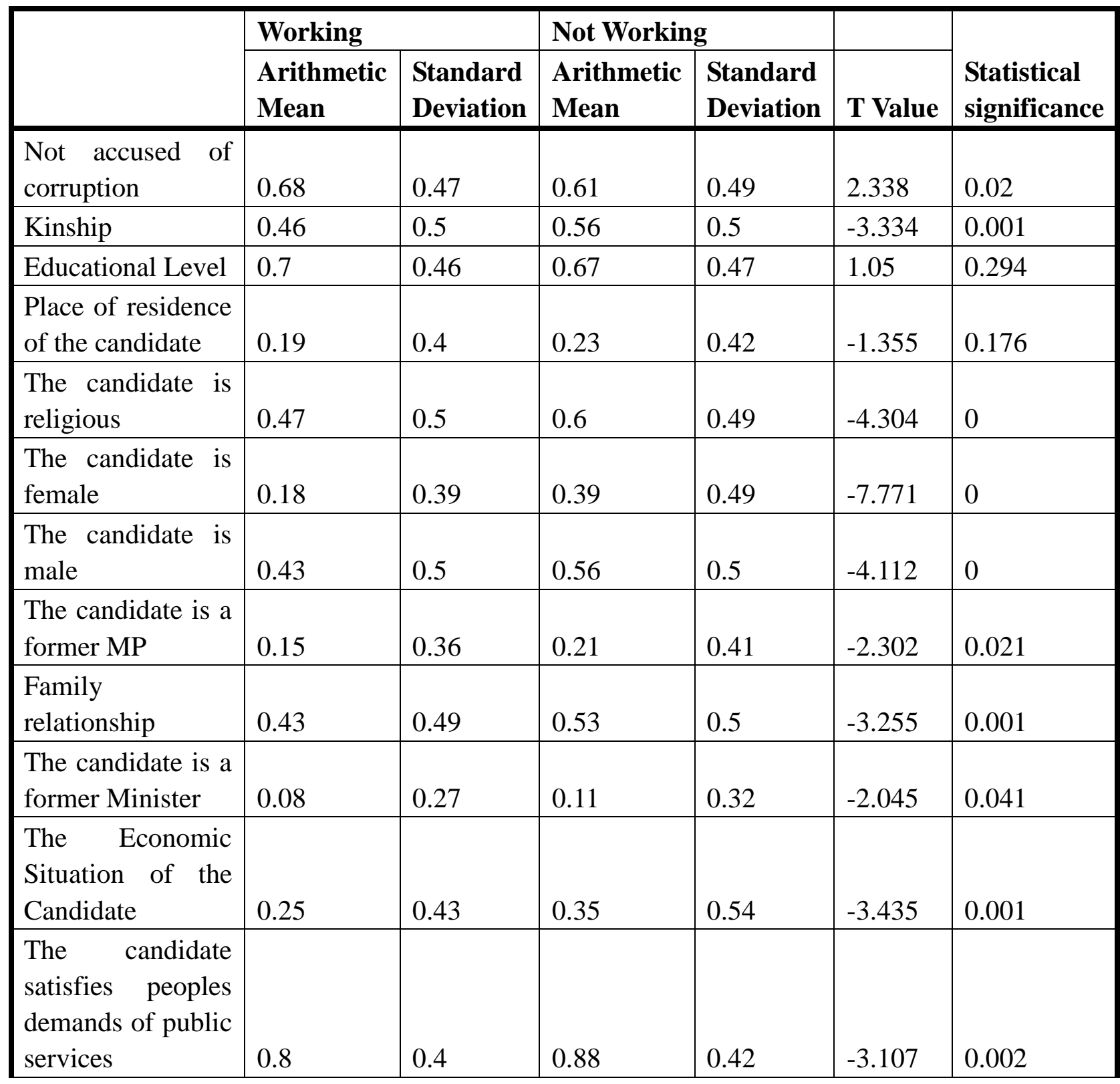




\begin{tabular}{|l|l|l|l|l|l|l|}
\hline $\begin{array}{l}\text { The candidate is } \\
\text { able to draw } \\
\text { legislations }\end{array}$ & 0.44 & 0.5 & 0.49 & 0.56 & -1.711 & 0.087 \\
\hline $\begin{array}{l}\text { The candidate is } \\
\text { able to keep the } \\
\text { executive } \\
\text { authority } \\
\text { accountable the }\end{array}$ & 0.6 & 0.49 & 0.62 & 0.55 & -0.552 & 0.581 \\
\hline $\begin{array}{l}\text { Whether pays } \\
\text { candidate } \\
\text { money for votes }\end{array}$ & 0.19 & 0.39 & 0.17 & 0.38 & 0.655 & 0.513 \\
\hline
\end{tabular}

Table (8) shows the presence of statistically significant differences $(\alpha \leq 0.05)$ due to the "Work" in all categories except the "Educational Level", the "Place of residence of the candidate", the "The candidate is able to draw legislations", the "The candidate is able to keep the executive authority accountable" and the "Whether the candidate pays money for votes". Differences were in favor of the "Not working" in each of the categories: "Kinship", "The candidate is religious", "The candidate is female", "The candidate is male", "The candidate is a former MP", "Family relationship", "The candidate is a former Minister", "The Economic Situation of the Candidate", and the "The candidate satisfies peoples demands of public services", while these differences were in favor of the "Working" in the category "Not accused of corruption.

\section{Review of the results:}

The attributes displayed by the candidate play a big role in his selection as an MP, because the voters view him as a guardian of their interests, and a representative of them to convey their concerns to the executive authority, therefore, voters try to select the candidate who enjoys the attributes that enable him to represent them in the legislative authority, and convey their concerns and aspirations honesty and sincerity away from giving advancing the private interest of the candidate over the public interest. In order to achieve the objectives of the study, its results were analyzed and classified according to arithmetic mean for each attribute, so that the upper arithmetic mean of the attribute is the most widely accepted. The results of the study showed the following order of the attributes:

\section{The candidate satisfies people's demands of public services}

Obtained the first rank with an arithmetic mean of 0.82 among the attributes seen by the Jordanian voter as qualifying for a member of the upcoming Lower House of Representatives as the issue of services is one of the big problems facing the Jordanian people, therefore, it is 
found that Jordanian voter gives this attribute a great importance when selecting a member of the Lower House of Representatives. This indicates the extent of agreement among the citizens to give this attribute an important place, and without any discrepancy between them, in the sense that there is almost unanimity on considering this attribute as the first and distinctive attribute of the member of the upcoming Lower House of Representatives. This, however, is a clear indicator of the absence of justice in distribution of the public services and development returns by the executive authority among the people, it is also an indication of the spread of cronyism, nepotism and lack of transparency.

\section{Educational level of the candidate}

The Jordanian people are considered of the world's most educated and interested in education; they look to education, since long, as one of the types of investment in people; accordingly, the Jordanian citizens assume the importance of their deputies to enjoy a suitable level of education to commensurate with and functions to be exercised by the deputies to be beneficial to the nation and the citizen in view of the high productivity exercised by the educated person, and the insightful outlook for sustainable development. Therefore, this attribute obtained the second place of importance.

\section{Not accused of corruption}

Obtained the third place, with an arithmetic mean of 0.66 among the attributes that are viewed by the Jordanian voter as qualifying for a member of the upcoming Lower House of Representatives as the issue of corruption is a major problem facing the Jordanian people, whereby many public figures were accused, including members of the Lower House of Representatives. Among the widespread forms of corruption was the private benefiting of public money, giving public jobs to relatives and acquaintances, and obtaining some privileges, etc.; therefore, it is found that the Jordanian voter gives this attribute a degree of importance in choosing the Member of Parliament. This indicates the extent of agreement among the citizens to give this attribute an important place, and without any discrepancy between them, in the sense that there is almost unanimity on considering this attribute is a characteristic of the member of the upcoming Lower House of Representatives and a clear indicator of the lack of control and accountability.

\section{The candidate is able to control the executive authority}

ranked fourth, and obtained an arithmetic mean of 0.60 among fifteen attributes viewed by the Jordanian voter as necessary in the member of the upcoming Lower House of Representatives; this is an indication of the Jordanian voter's awareness of one of the most important tasks of a member of the Lower House of Representatives, i.e., monitoring and accountability of the executive authority, as a means of fighting corruption, favoritism and nepotism, and in order to build the state of institutions and law, and the rule of the principles of transparency and accountability. 


\section{The candidate is religious}

ranked fifth with an arithmetic mean of 0.50 , as the Jordanian society is affected largely by religion, and generally assumes integrity, good character, good performance and honesty in a religious person, regardless of the political stream represented by this candidate.

\section{Kinship}

Results showed that this attribute will play a role in the upcoming elections, for considerations related to the individual and the family, in the sense that voters care about the Jordanian candidate who is bound by kinship ties.

\section{The candidate is male}

Results showed that this character will play a moderate role in the next elections, the gender of the candidate, however, is one of the attributes that caught the attention of the Jordanian voters when selecting a member of the upcoming Lower House of Representatives. The chose the male candidate over the female, because the Jordanian society, as is the Arab society, a male oriented society, and gives more attention to the males than the females; males still bear the responsibility, and the society gives him room for movement and mixing freedom more than females.

\section{Family relationship}

This attribute refers to the historical, economical and social background of the family of the candidate, and the role of his family at the level of the nation and the region, and this is reflected on the Jordanian voter's choice when selecting the candidate.

\section{The candidate is able to draw legislations}

This attribute was ranked ninth among the fifteen attributes the Jordanian voters view as needed in the Jordanian candidate for the elections, with a medium degree; this indicates the voter's awareness of another role of the member of the Lower House of Representatives as well as the control.

\section{The economic situation of a candidate}

Which means the financial position of the candidate, where capital plays an important role in the political, economic and social life, through the establishment of companies and factories which has provided employment for many of the workforce, and therefore, contributed to the reduction of unemployment and poverty. Accordingly, this attribute was given this status of significance by the voter hoping that owners of capital would participate in the improvement 
of the development of the citizen and the community conditions.

\section{The candidate is female}

Despite the important roles played by Jordanian women in all aspects of life, her role in decision-making and leadership of institutions does not commensurate with here other roles, and therefore, it is found that this attribute was ranked in the rear, compared to the attribute that the candidate is male. Nonetheless, there is a trend among the people trying to give women their role in political life through introducing the system of women quota.

\section{Place of residence of the candidate}

Which refers to the candidate living in the same area where he would be nominated, as the voter views the candidate a person who would feel his daily worries and be available in his area continuously.

\section{Whether the candidate pays money for the vote}

This is an attribute which started to appear recently in the considerations of some voters, and is so-called "political money" and "vote buying", this attribute, however, was ranked thirteenth and with a lower degree of, but is more important to voters than the fact of the candidate being a former deputy or a former Minister. It is an indication of the generally poor economic situation and high rates of poverty and unemployment.

\section{The candidate is a former deputy}

Ranked quite late to indicate the lack of confidence and the dissatisfaction of the Jordanian voter in the performance of the majority of members of the previous Houses of Representatives, therefore, it is not so important in view of the voter whether the candidate is a former deputy as he was tried and judging him is possible by all.

\section{The candidate is a former Minister}

This attribute was ranked last, to indicate the absence of the role and impact of Ministers, and therefore the executive authority in the lives of members of the society, or the nature of the relationship between the people and members of the executive authority which is based on the lack of trust and respect strengthening the skepticism between them. 


\section{Macrothink}

\section{Summary of the Results:}

Following is a summary of the most important conclusions of this study:

- Among the most important attributes that the Jordanian voter deems appropriate in the member of the Jordanian Lower House of Representatives:

- That the candidate satisfies people's demands of public services, his educational level, and that he is not accused of corruption; in contrast, to a lower degree the voter is interested in the fact that the candidate is a former Minister or a former deputy, or pays money for the vote.

- The presence of statistically significant differences $(\alpha \leq 0.05)$ due to the effect of "Gender" in each of "kinship", "educational level", "the candidate is religious", "the candidate is female", "the candidate is male", "family relationship", and "the candidate pays money for the vote".

- The presence of statistically significant differences $(\alpha \leq 0.05)$ due to the effect of "Age" in each of "kinship", "educational level", "the candidate satisfies people's demands of public services", "the candidate is able to control the executive authority", and "the candidate pays money for the vote".

- The presence of statistically significant differences $(\alpha \leq 0.05)$ due to the effect of "Place of Residence" in all attributes except: "kinship", "the candidate is a former deputy", "family relationship", "the candidate satisfies people's demands of public services", and "the candidate pays money for the vote".

- The presence of statistically significant differences $(\alpha \leq 0.05)$ due to the effect of "Educational Level" in "not accused of corruption", "kinship", "educational level", "place of residence", "the candidate is female", "family relationship", "the candidate satisfies people's demands of public services", "the candidate is able to control the executive authority and "the candidate pays money for the vote".

- The presence of statistically significant differences $(\alpha \leq 0.05)$ due to the effect of "Work" in all attributes except in "educational level", "place of residence", "the candidate is able to draw legislations", "the candidate is able to control the executive authority and "the candidate pays money for the vote". 


\section{Macrothink}

\section{Recommendations}

In light of the results of this study; the following recommendations may be suggested:

- The Jordanian political powers and parties and as well as tribal powers, upon entering the parliamentary elections in 2010, must chose the candidate who combines the ability to satisfy the needs of people of public services, and the suitable academic qualification, in addition to the cleanliness of his hand, in order to be eligible to win the election.

- The Jordanian voter must participate effectively in the parliamentary elections in 2013, to achieve the required change, and to select representatives and leaders who can handle the tasks of control, accountability, and legislation.

- The Jordanian society, women in particular are required to intensify awareness campaigns, particularly among females to highlight the role of women in the Jordanian society, and their ability to take responsibility in leading positions with the males.

- The presence of a strong, effective and independent Lower House of Representatives who undertakes his legislative functions, duly controls the executive authority, strengthens the relationship with the people, and strengthens the role of the fourth authority, requires members of the Lower House of Representatives who combine the "ability to satisfy peoples' requirements of public services", "academic qualification", "is not accused of corruption", "the candidate is capable to monitor the executive authority", "the candidate religious"," kinship", "the candidate is male", "family relationship", and the candidate is able to draw legislations.

- The commitment of the Jordanian voter in the above requirements which obtained the unanimity of a majority of the study sample, may lead to a stable and effective government, which belongs and encourages consensus and convergence between the parties and various political powers, and accepts a real and effective parliamentary opposition. 


\section{Bibliography}

Al Masri, M. (2007). Public Opinion Poll on the Evaluation of the Performance of the Fourteenth Lower House of Representatives (2003 - 2007) and the Determinants of Voting Behavior During the Upcoming parliamentary Elections. The University of Jordan Center for Strategic Studies, Public Opinion Poll Unit, November, Amman.

Al Omari, I. (1997). Impact of the Social Politicization on the Jordanian Parliamentary Elections, unpublished Master's thesis, the University of Jordan, Amman.

Al Rai Newspaper. (1998). Parliamentary Elections in a Dialogue Paper, August, September and October.

Alotain, S. (2006), Political Pluralism in Light of the Jordanian Parliamentary Elections 1989 - 2005, Unpublished Master's thesis, Al al-Bayt University, Al Mafraq.

Alzioud, M. E. (2000). Clan and the Parliamentary Elections in Jordan, Unpublished Master's Thesis, the University of Jordan, Amman.

Bani Amer, A. (2010). The youth Orientations to Participate in the Upcoming Parliamentary Elections, Al Hayat Center for Civil Society Development, Amman.

Center for Strategic Studies. (2010). Public Opinion Poll on the New Elections Law and the Electoral Participation, Public Opinion Poll Unit, Amman.

El-Horani, H. and others. (1988). "Studies on the Jordanian Parliamentary Elections for 1997”. Jordan New Center for Studies, Amman.

New Al Mashriq Center for Studies. (2007). Upcoming Parliamentary Elections, Amman, 28 September.

The International Republican Institute. (2009). Jordanian Public Opinion Poll on the Democratic Reform and Political Reconciliation in Jordan, 8 - 11, August.

Websites:

- aljazeera.net/books/2003/6/6-14-1.htm

- www.achrs.org 